\title{
JUURNAL.RU
}

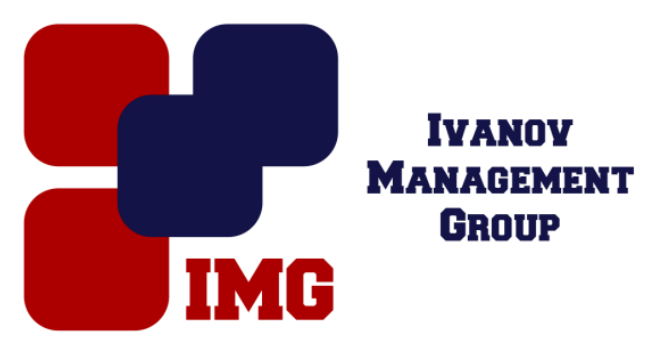

Костина К.С.

Курский Государственный Университет

Курск, Россия

doi: $10.18411 / 1 \mathrm{j}-31-05-2017-25$

idsp 000001:1j-31-05-2017-25

\section{Проблема развития художественных умений учащихся ДХШ в процессе выполнения экслибриса}

\section{Аннотация:}

В статье отмечается необходимость развития графической культуры учащихся ДХШ. Автором называются основные проблемы, возникающие у подростков в изобразительной деятельности. Предлагается разработка программы элективного курса «Экслибрис» призванная качественно повысить уровень художественных умений учащихся ДХШ.

Ключевые слова: графическая культура, художественные умения, экслибрис.

На сегодняшний день в современной системе образования со стороны государства наблюдается повышенное внимание к значимости художественного образования. Доказательством тому служит принятие следующих основополагающих документов, таких как: Закон Российской Федерации «Об образовании», «Концепция системной модернизации сельской школы России», «Концепция художественного образования в Российской Федерации». В содержании которых отмечается ориентированность художественного образования в ДХШ на подготовку прогрессивных, творчески мыслящих и активных подростков, являющихся носителями культурных ценностей и традиций, востребованных в образовательных учреждениях, достигаемые средствами изобразительного искусства.

Научить подростка осознанно использовать основы изобразительной грамоты, пользоваться им как средством, позволяющим с наибольшей полнотой 
выражать свое представление об окружающей действительности, передавать в рисунке настроение, состояние, характер образа, выражать к нему свое отношение - одна из важнейших задач развития изобразительного творчества.

Исследователями замечено, что, достигнув подросткового возраста, обучающиеся теряют интерес к рисованию. Эта проблема исследовалась А.В. Бакушинским, В.С. Щербаковым, Б. Эдвардсом и др. Они отмечают, что уровень самосознания подростков превышает уровень их художественных возможностей в изобразительной деятельности.

В статье Шабановой О. П., Шабановой М. Н. «Модель преодоления низкого уровня графической культуры студентов и школьников» отмечается необходимость привития обучающимся графической культуры «возраст подростка является наиболее благоприятным для оперативности, динамичности, подвижности, широты и полноты оперирования пространственными образами. Поэтому совершенно логично именно в этот период введение школьного предмета, предполагающего работу с формой.»

«Графическая культура - базовое, интегральное качество личности, проявляющееся в высоком уровне владения и оперирования знаниями в области графики, в осознании их ценности для профессионального будущего, в способности к анализу и прогнозированию производственного процесса, базирующейся на использовании геометро-графического потенциала для эффективного решения профессиональных задач.» [1]

На наш взгляд, содействовать привитию обучающимся графической культуры позволит программа элективного курса «Экслибрис», так как она предоставит возможность подросткам овладеть формами стилизации, открыть для себя богатство графических средств и научить использовать их в собственном творчестве. Графика позволяет сконцентрировать внимание зрителя на содержании и композиционном построении произведения. Поэтому экслибрис в графике послужит эффективным средством развития художественных умений, так как направит подростков к форме интуитивного познания и мышления, а не свойственного им логического. Так же он поспособствует процессам абстрагирования в мышлении подростков, что поможет воспринимать изображаемое цельно.

Программа элективного курса «Экслибрис» рассчитана на 23 часа и ориентирована на возрастную категорию учащихся ДХШ от 11- 14 лет.

В рамках нашей программы нами была разработана пояснительная записка, в которой подробно излагается цель, задачи, принципы, критерии и 
уровни, методы и результат. В содержание данной программы входит система упражнений и заданий, направленных на переход художественных умений на качественно новый уровень посредством разработки личного экслибриса.

Таким образом, разработка программы элективного курса «Экслибрис» определяет проблему развития художественных умений учащихся ДХШ актуальной в рамках системы современного художественного образования. Решение этой проблемы заложено в процессе творческой деятельности и в ходе решения проблемно-творческих задач.

1. Шабанова О. П., Шабанова М. Н. Модель преодоления низкого уровня графической культуры студентов и школьников // Ученые записки. Электронный научный журнал Курского государственного университета. 2014. №1 (29) С.199-204.

2. Ломов, С.П. Методология художественного образования / С.П. Ломов, Аманжолов С.А.М.: Прометей, 2011. 